\title{
Uncertain Dependance on Modern Tools in Multiplexes for Purchasing Household Commodities
}

\author{
C. Archanapriya, M.M. Shanmugapriya, S. Janifer Vinnarasi
}

\begin{abstract}
This paper involves the study of the reasons why generally people prefer hyper market stores and know the various medias which influences the customers to hypermarket. Illuminating assessment is used in this examination since it will ensure the minimization of reason and expansion of resolute nature of data accumulated. This choice was invited by financial analysts and the business sectors, however caused fights and a change in India's focal government's political alliance structure...
\end{abstract}

Keywords: hyper market stores, financial analysts

\section{INTRODUCTION}

Retailing in India is one of the mainstays of its economy and records for around 10 percent of its GDP. The Indian retail market is evaluated to be US\$ 600 billion and one of the best five retail advertises on the planet by financial worth. India is one of the quickest developing retail advertises on the planet, with 1.2 billion individuals.

Starting at 2003, India's retailing industry was basically proprietor kept an eye on little shops. In 2010, bigger arrangement accommodation stores and grocery stores represented around 4 percent of the business, and these were available just in enormous urban focuses. India's retail and coordinations industry utilizes around 40 million Indians (3.3\% of Indian populace).

Until 2011, Indian focal government denied outside direct venture (FDI) in multi-brand retail, denying remote gatherings from any proprietorship in grocery stores, comfort stores or any retail outlets. Indeed, even single-brand retail was constrained to $51 \%$ proprietorship and a bureaucratic procedure. [1]-[5]

. An examiner from Fitch Group expressed that the 30 percent prerequisite was probably going to essentially postpone if not avert most single brand majors from Europe, USA and Japan from opening stores and making related occupations in India.

Revised Manuscript Received on December 11, 2019

C. Archanapriya, Assistant Professor, Department Of Science \& Humanities,Bharath Institution Of Higher Education And Research TamilNadu,India Email: Archanapriya854@gmail.com

M.M. Shanmugapriya, Assistant Professor, Department Of Science \& Humanities,Bharath Institution Of Higher Education And Research TamilNadu,India Email: priyashammu@gmail.com

S. Janifer Vinnarasi Assistant Professor, Department Of Science \& Humanities,Bharath Institution Of Higher Education And Research TamilNadu,India Email: mjjaa24@gmail.com
This choice was invited by financial analysts and the business sectors, however caused fights and a change in India's focal government's political alliance structure. On 20 September 2012, the Government of India officially told the FDI changes for single and multi brand retail, in this manner making it successful under Indian law.

On 7 December 2012, the Federal Government of India permitted $51 \%$ FDI in multi-brand retail in India. he administration figured out how to get the endorsement of multi-brand retail in the parliament notwithstanding overwhelming hubbub from the resistance (the NDA and radical gatherings). A few states will permit remote markets like Walmart, Tesco and Carrefour to open while different states won't.[6]-[8]

\section{OBJECTIVES OF THE STUDY}

1. To find out the Reasons why the customers prefer hyper market

2. To know the various medias which influences the customers to hypermarket

\section{METHODOLOGY}

The procedure used to gather data and information with the end goal of making business decisions. The philosophy may incorporate publication research, meetings, overviews and other research methods, and could incorporate both present and chronicled data.

\section{A. Wellspring of Data}

The information can be gathered from essential and optional sources.

\section{B. Essential Data:}

Essential information implies unique information that has been gathered extraordinarily for the reason as a top priority. It implies somebody gathered the information from the first source direct. Information gathered along these lines is called essential information.

\section{Sample Size}

The sample size of the 100 respondents was considered appropriate keeping in view the objective and limitation Sampling Area Sampling area may be a geographical

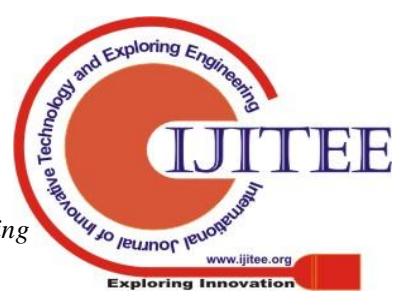




\section{Uncertain Dependance on Modern Tools in Multiplexes for Purchasing Household Commodities}

one, such as a state, district, village etc.

The researcher will have to decide one or more of such area that he has to select for his study. The study is conducted among the customers of hyper stores in chennai. They have been further classified as male and female.

\section{HYPOTHESIS OF THE STUDY}

1. H0: There is no significant relationship between Gender and reason for visiting

H1: There is a significant relationship between Gender and reason for visiting.[13]-[18]

\section{RESULTS ANALYSIS AND INTERPRETATION}

\begin{tabular}{|c|c|c|c|c|c|}
\hline Customer Retention ways & $\mathbf{N}$ & Minimum & Maximum & Mean & Std. Deviation \\
\hline \begin{tabular}{|l|} 
Attractive advertising \\
\end{tabular} & 100 & 1 & 5 & 4.12 & .902 \\
\hline $\begin{array}{l}\text { Meeting customer } \\
\text { expectations }\end{array}$ & 100 & 1 & 5 & 3.89 & .886 \\
\hline Free offers & 100 & 2 & 5 & 3.85 & .821 \\
\hline Bunding & 100 & 1 & 5 & 3.77 & .983 \\
\hline Free door delivery & 100 & 1 & 5 & 3.51 & 1.078 \\
\hline Gift coupons & 100 & 1 & 5 & 3.83 & .965 \\
\hline Vouchers & 100 & 1 & 5 & 3.69 & 1.089 \\
\hline Accept credit cards & 100 & 1 & 5 & 4.18 & .869 \\
\hline Games & 100 & 1 & 5 & 3.58 & .976 \\
\hline Social medias & 100 & 1 & 5 & 3.82 & .968 \\
\hline Regular reviews & 100 & 1 & 5 & 3.66 & 1.007 \\
\hline Better communication & 100 & 1 & 5 & 3.61 & 1.024 \\
\hline \begin{tabular}{|l} 
Spending time with \\
customers \\
\end{tabular} & 100 & 1 & 5 & 3.70 & .823 \\
\hline Special day surprises & 100 & 1 & 5 & 3.71 & .957 \\
\hline Kesp up promises & 100 & 1 & 5 & 3.60 & 1.015 \\
\hline Valid N (liatspiae) & 100 & & & & \\
\hline
\end{tabular}

\section{INTERPRETATION}

it is clear that the attractive advertising has the highest mean value of 4.18. This says that hyper market stores uses the customer retaining strategy through accepting credit cards. The next highest mean value is 4.12 that is attractive advertising, the next highest value is 3.89 that is meeting the customer's requirements was another retention strategy used by Big Bazaar. Free Offers is another strategy used to retain the customers it has the higher mean value of about 3.85 . [19]-[25]

\section{HYPOTHESIS - 1}

$\mathrm{H} 0$ : There is no significant relationship betweenGender and reason for visiting

H1: There is a significant relationship betweenGender and reason for visiting[9]-[12]

\section{FINDINGS}

The following are the findings of the study:-

- Majority of the respondents belong to the age category of $18-22$ i.e. $50 \%$

- Most of the respondents are Female which is about $67 \%$

- The most of the respondent's annual income is less than 1 Lakh.
- Most of the customer's opinion is that they have a freedom of choice. Therefore they can select whatever the products they want.

- The customers also visit hyper market stores because of its store design and its ambience

- Some of the customers visit hyper market stores because they are easy to access and some visit because of its Brand name.

- The most important ways through which the customers are retained by Big Bazaar are accepting credit cards, attractive Advertising, meeting customers' expectations and Free Offers.

- Most of the respondents are satisfied with the customer service as well as the online services of Big Bazaar.

The following are some of the suggestions given by the respondents:-

- hyper market stores management should concentrate on electronic goods and cloths for improving the sales of those products.

- hyper market stores management has to give more offers to their products for generating sales.

- hyper market stores sales persons should improve their skills to give good service to the customers

- Customer service department should increase their response time to the customer needs.

To maintain a proper relationship with the customers was considered to be the main motive of Big Bazaar. But still the management should focus more of their cons in order to improve customer relationship with the customers. This helps the Big Bazaar management to do all changes within them. There is a lack of advertising media in Big Bazaar with the customers which can also be taken into consideration for their growth and development.

. Most of the staff are not aware about the different sections and the products which are available under such sections. Therefore the employees can be well trained so that this can be a factor to develop customer relationship.

A proper customer relationship management can always make the Management to develop themselves in terms of their growth and also their company's exposure.

\section{Gender and Freedom of choice}
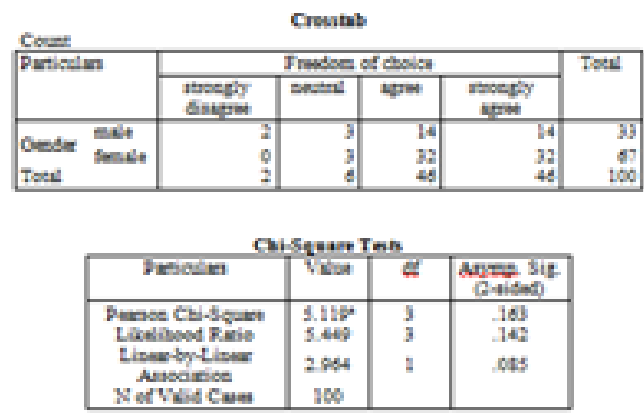

Published By: 
hence it can be concluded that there is nosignificant relationship between Age and reason for visiting with regard to freedom of choice.

The following are the findings of the study:-

- Majority of the respondents belong to the age category of $18-22$ i.e. $50 \%$

- Most of the respondents are Female which is about $67 \%$

- The most of the respondent's annual income is less than 1 Lakh.

- Most of the customer's opinion is that they have a freedom of choice. Therefore they can select whatever the products they want.

- The customers also visit hyper market stores because of its store design and its ambience

- Some of the customers visit hyper market stores because they are easy to access and some visit because of its Brand name.

- The most important ways through which the customers are retained by Big Bazaar are accepting credit cards, attractive Advertising, meeting customers' expectations and Free Offers.

- Most of the respondents are satisfied with the customer service as well as the online services of Big Bazaar.

The following are some of the suggestions given by the respondents:-

- hyper market stores management should concentrate on electronic goods and cloths for improving the sales of those products.

- hyper market stores management has to give more offers to their products for generating sales.

- hyper market stores sales persons should improve their skills to give good service to the customers

- Customer service department should increase their response time to the customer needs.

To maintain a proper relationship with the customers was considered to be the main motive of Big Bazaar. But still the management should focus more of their cons in order to improve customer relationship with the customers. This helps the Big Bazaar management to do all changes within them. There is a lack of advertising media in Big Bazaar with the customers which can also be taken into consideration for their growth and development.

. Most of the staff are not aware about the different sections and the products which are available under such sections. Therefore the employees can be well trained so that this can be a factor to develop customer relationship.

A proper customer relationship management can always make the Management to develop themselves in terms of their growth and also their company's exposure.

\section{REFERENCES}

1. Vasanthi, S. \& Rabiyathul Basariya, S. 2019, "Influence of value analysis and cross training in industry", International Journal of Engineering and Advanced Technology, vol. 8, no. 6, pp. 1810-1811.

2. Velvizhi, R., Sri Gowtham, S. \& Jeya Priya, D. 2019, "Examination of early feedbacks for effective product retailing on E-commerce websites", International Journal of Engineering and Advanced Technology, vol. 8, no. 6 Special Issue 2, pp. 703-706.

3. Anuradha, C., Pothumani, S. \& Kavitha, R. 2019, "A novel method towards E-commerce", International Journal of Engineering and Advanced Technology, vol. 8, no. 6 Special Issue 2, pp. 535-538.

4. Thomas, J. \& Rabiyathul Basariya, S. 2019, "A study on the issues of financial ratio analysis", Indian Journal of Public Health Research and Development, vol. 10, no. 3, pp. 1079-1081.

5. Ramachandran, S. \& Rabiyathul Basariya, S. 2019, "Online marketing study on customer satisfaction and relationship", Indian Journal of Public Health Research and Development, vol. 10, no. 3, pp. 1072-1078.

6. Priya, R., Vinothini, G. \& Cor Jesu, C.D. 2019, "The mentor-protégé relationship for professional growth", Journal of Advanced Research in Dynamical and Control Systems, vol. 11, no. 9 Special Issue, pp. 1110-1119.

7. Jannifer Rani, N., Bina Pani, S. \& Nimisha, N.S. 2019, "A study on money back polices available in LIC", Journal of Advanced Research in Dynamical and Control Systems, vol. 11, no. 9 Special Issue, pp. 833-839.

8. Saillaja, V., Jhansi Rani, K. \& Catherine, R. 2019, "Global marketing management planning and organization", Journal of Advanced Research in Dynamical and Control Systems, vol. 11, no. 9 Special Issue, pp. 489-493.

9. Saillaja, V., Jhansi Rani, K. \& Catherine, R. 2019, "The new phase of marketing information system", Journal of Advanced Research in Dynamical and Control Systems, vol. 11, no. 9 Special Issue, pp. 482-488.

10. Thoufiqulla \& Raju, D.V. 2019, "Perception of indian investor towards investment in mutual funds with special reference to mip funds", Journal of Advanced Research in Dynamical and Control Systems, vol. 11, no. 5, pp. $177-183$.

11. Jasmine, K.R.M. \& Basariya, S.R. 2018, "A study on the customers benefits on mutual funds", International Journal of Civil Engineering and Technology, vol. 9, no. 4, pp. 45-48.

12. Vasanthi, S. \& Basariya, S.R. 2019, "Pros and cons of on the job training versus off the job training", International Journal of Scientific and Technology Research, vol. 8, no. 10, pp. 671-674.

13. Pavithra, J. \& Ganesan, M. 2016, "A study on awareness and impact of micro-financial schemes", International Journal of Applied Business and Economic Research, vol. 14, no. 8, pp. 5449-5460.

14. Pavithra, J., Dilli Babu, P. \& Ambuli, T.V. 2014, "A study on budgetary control at Maruti Service Masters, Chennai", International Journal of Applied Business and Economic Research, vol. 12, no. 2, pp. 151-161.

15. Gunaraja, T.M. \& Venkatrama Raju, D. 2018, "Determining factors of organisational climate with reference to leadership styles", International Journal of Mechanical Engineering and Technology, vol. 9, no. 9, pp. 1327-1332.

16. Gunaraja, T.M. \& Venkatrama Raju, D. 2018, "The role of job satisfaction and training of employees in determining organisational climate of a selected industry", International Journal of Civil Engineering and Technology, vol. 9, no. 8, pp. 1266-1269.

17. Aarathy, T.S. \& Raju, D.V. 2018, "Performance appraisal and its effects on employees with respect to it sector in Chennai city", International Journal of Civil Engineering and Technology, vol. 9, no. 6, pp. 1535-1538.

18. Aarathy, T.S. \& Raju, D.V. 2018, "Employee perception towards performance appraisal system in IT sector", International Journal of Mechanical Engineering and Technology, vol. 9, no. 5, pp. 131-135.

19. Porselvi, W., Jublee, D. \& Sivanesan, G. 2018, "A study on factors influencing adoption of technology and innovation in banking industry, tamilnadu, India", International Journal of Mechanical Engineering and Technology, vol. 9, no. 5, pp. 789-800.

20. Akessa, G.M. and Dhufera, A.G., 2015. Factors That Influences Students Academic Performance: A Case of Rift Valley University, Jimma, Ethiopia. Journal of Education and Practice, 6(22), pp.55-63.

21. Miller, G. and Shih, C.C., 1999. A faculty assessment of the academic rigor of on-and off-campus courses in agriculture. Journal of Agricultural Education, 40, pp.57-65.

22. Tsinidou, M., Gerogiannis, V. and Fitsilis, P., 2010. Evaluation of the factors that determine quality in higher education: an empirical study. Quality Assurance in education, 18(3), pp.227-244.

23. Farooq, M.S., Chaudhry, A.H., Shafiq, M. and Berhanu, G., 2011. Factors affecting students' quality of academic performance: a case of secondary school level. Journal of quality and technology management, 7(2), pp.1-14. 
24. Fitsilis, P., Gerogiannis, V. and Anthopoulos, L., 2014. Ontologies for software project management: a review. Journal of Software Engineering and Applications, 7(13), p.1096.

25. Adams, J.D. and Jaffe, A.B., 1996. Bounding the effects of R\&D: an investigation using matched establishment-firm data(No. w5544). National bureau of economic research.

\section{AUTHORS PROFILE}

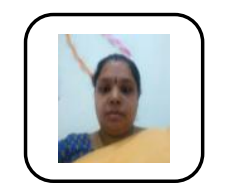

C. Archanapriya, Assistant Professor, Department Of Science \& Humanities,Bharath Institution Of Higher Education And Research TamilNadu,India

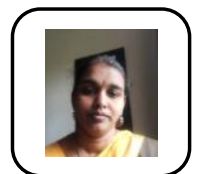

M.M. Shanmugapriya, Assistant Professor, Department Of Science \& Humanities,Bharath Institution Of Higher Education And Research TamilNadu,India

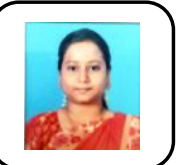

S. Janifer Vinnarasi Assistant Professor, Department Of Science \& Humanities Bharath Institution Of Higher Education And Research TamilNadu,India 